\title{
Peningkatan Budaya Belajar-Mengajar Dan Reputasi Sekolah Melalui Penerapan Sistem Monitoring Pembelajaran Online
}

\author{
Rudi Walujo Prastianto ${ }^{1}$, Mahmud Mustain ${ }^{2}$, Herman Pratikno ${ }^{3}$, Handayanu ${ }^{4}$, Dwi Purnomo $\mathrm{H}^{5}$, \\ Zuhud Ubaidillah $^{6}$, Miftakh D. ${ }^{7}$ \\ Departemen Teknik Kelautan FTK ITS Surabaya \\ rudiwp@gmail.com ${ }^{1}$, mmustain@oe.its.ac.id ${ }^{2}$, hermankelautan@gmail.com ${ }^{3}$, \\ handayanu@oe.its.ac.id ${ }^{4}$, dphendra@its.ac.id ${ }^{5}$
}

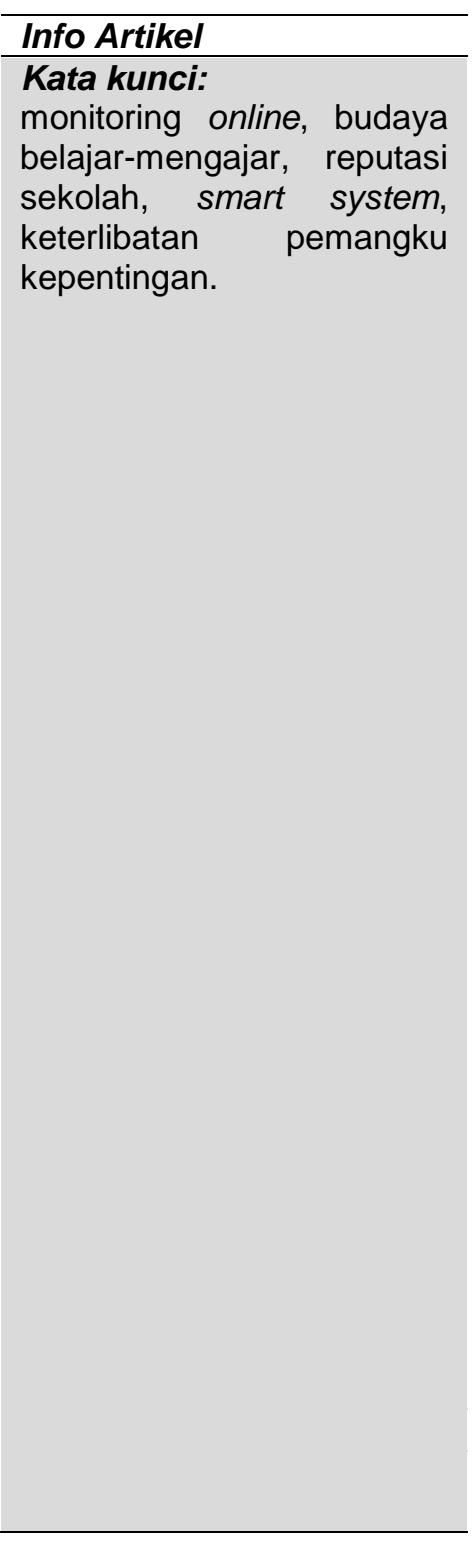

\begin{abstract}
Abstrak
Inovasi teknologi untuk pendidikan mutlak dibutuhkan di era Revolusi Industri 4.0, karena teknologi digital dapat memberikan solusi terhadap permasalahan masyarakat di sektor pendidikan. Fleksibilitas, efektifitas dan efisiensi penggunaan teknologi yang tepat dapat menembus ruang dan waktu dalam menjembatani komunikasi antar para pemangku kepentingan dalam proses pendidikan. Penerapan sistem monitoring pembelajaran online sebagai kegiatan pengabdian kepada masyarakat oleh Departemen Teknik Kelautan FTK-ITS dengan mitra sekolah AI Uswah Surabaya, menjadi solusi terhadap sistem yang masih konvensional yang kurang efektif dan efisien serta rentan terhadap ketidakakuratan akibat kesalahan manusia. Pada akhirnya, dengan sistem ini dapat memperbaiki pelayanan dan kinerja, sehingga efektivitas dan efisiensi proses tersebut meningkat. Parameter penting yang direkam menjadi database oleh sistem monitoring pembelajaran terkait kehadiran siswa, kehadiran guru dan durasi waktu proses belajar mengajar dapat dianalisis secara statistik deskriptif. Fitur sistem yang mampu diakses orang tua siswa, bahkan dapat menjadi media promosi untuk meningkatkan reputasi sekolah serta peran serta orang tua/wali siswa dalam mendukung kesuksesan kegiatan pendidikan. Sistem elektronik ini tidak akan memberikan hasil optimum jika tidak diiringi dengan perubahan pemahaman dan perbaikan budaya belajar mengajar guru, siswa, serta manajemen sekolah. Atau sebaliknya, dengan kehadiran sistem ini secara tidak langsung dapat memaksa untuk terjadinya perubahan budaya belajar-mengajar ke arah yang lebih baik secara bertahap. Dalam penelitian ini parameter penting terkait kegiatan proses belajar mengajar selanjutnya dianalisis untuk menemukan hubungan yang mendukung hipotesis terkait peningkatan budaya belajar mengajar dan reputasi sekolah melalui penggunaan sistem berbasis teknologi komunikasi dan informasi ini.
\end{abstract}

\section{PENDAHULUAN}

Di dalam Peraturan Menteri Riset, Teknologi dan Pendidikan Tinggi Nomor 44 tahun 2015 tentang Standar Nasional Pendidikan Tinggi tertulis bahwa di dalam proses pembelajaran yang efektif tentunya perlu suatu monitoring dan evaluasi (monev) agar tujuan dapat dicapai. Di sisi lain, kegiatan monev internal merupakan salah satu bentuk pertanggungjawaban Perguruan Tinggi untuk menjamin bahwa pelaksanaan kegiatan akademik sudah sesuai dengan aturan dan mencapai target yang telah ditetapkan. Melalui kegiatan monev ini juga, persoalan dan kendala yang dihadapi dalam 
implementasi dapat diantisipasi dan ditanggulangi, serta apa yang dilaksanakan oleh dosen menjadi lebih terarah dan sesuai dengan standar yang ada.

Proses monitoring dan evaluasi adalah salah satu instrumen Penjaminan Mutu dalam proses pembelajaran pada setiap semester yang bertujuan untuk memantau penerapan standar proses pembelajaran yang telah ditetapkan. Monitoring merupakan kegiatan pemantauan yang dilakukan untuk mengetahui kegiatan proses pembelajaran yang dilakukan oleh pengajar (dosen/guru). Sedangkan evaluasi adalah hasil akhir dari proses analisis terhadap hasil monitoring selama proses belajar mengajar yang dilakukan selama satu semester.

Dalam proses pembelajaran, kegiatan monitoring dan evaluasi dapat menghasilkan data seperti materi yang disampaikan pengajar untuk tiap pertemuan kuliah, durasi proses belajar-mengajar, kehadiran (durasi keterlambatan) pengajar dan peserta didik, serta jenis ketidakhadiran peserta didik.

Jika pelaksanaan monev masih dilakukan secara manual dengan cara menuliskan di lembar kertas, maka masih banyak kelemahannya seperti informasi dan data yang diperoleh tidak tepat waktu, dan tidak terlalu akurat akibat masih cenderung banyaknya human error. Sebagai solusinya maka digunakan suatu sistem informasi berbasis TIK yang bersifat online sehingga proses lebih efektif dan efisien, seperti data yang tepat waktu, mampu memberikan informasi yang valid dan akurat karena aspek human error dapat diminimalkan serta mendukung gerakan paperless yang ramah lingkungan.

Namun segala bentuk kemudahan yang diberikan oleh sistem online ini tentu akan memberikan dampak/konsekuensi logis, bahkan bisa positif atau negatif. Untuk itu dalam makalah ini akan dijelaskan dan dianalisis secara kualitatif pengaruh penerapan sistem monev pembelajaran online terhadap aspek peningkatan budaya belajar mengajar dan reputasi sekolah serta aspek terkait lainnya melalui parameter terbatas seperti kehadiran peserta didik, kehadiran pendidik dan durasi waktu proses belajar mengajar serta ketepatan materi ajar dengan silabus kurikulum yang berlaku.

\section{TINJAUAN PUSTAKA}

Proses monitoring dan evaluasi proses belajar mengajar memang dapat dilakukan secara manual/konvensional atau secara komputerisasi dengan teknologi informasi yang tersaji online. Banyak sekali peneliti yang sudah mengevaluasi atas penerapan kedua metode tersebut.

(Wenda, 2013) menggarisbawahi bahwa dalam pelaksanaannya proses monitoring manual masih banyak dilakukan dengan formulir dan dokumen yang berbentuk kertas, dengan kendala yang sering dijumpai adalah proses monitoring pertemuan yang dilakukan pada tiap akhir semester tidak bisa terkontrol secara otomatis, banyak memakan waktu untuk pengolahan dan membutuhkan ruang penyimpanan fisik.

Sebaliknya, dengan penerapan teknologi yang bersifat online banyak hal menjadi lebih efektif dan efisien menurut (Puspitasari, 2016), secara umum bahwa teknologi dapat menjadi solusi masalah pendidikan, terutama dalam membuka akses pendidikan menjadi lebih luas dan terbuka, sehingga pemanfaatan teknologi digital dapat memberikan solusi terhadap permasalahan masyarakat di sektor pendidikan.

Secara agak khusus, di satu sisi penggunaan sistem monitoring dengan komputerisasi telah dibuktikan mampu menghadirkan sebuah efisiensi waktu dalam prosesnya (Firdaus, 2011). Bahkan pada era Revolusi Industri 4.0 perkembangan perangkat keras dan integrasinya dengan teknologi informasi sangat terbuka lebar. Penerapan teknologi ini lebih lanjut juga dilakukan oleh (Anand, 2016) dalam pengembangan sebuah sistem presensi dalam proses belajar-mengajar dengan memanfaatkan teknologi smart phone yang digunakan untuk input dengan teknik pengenalan wajah dan mampu mendeteksi lokasi keberadaannya dengan memanfaatkan komunikasi Wi-Fi yang disediakan oleh kampus.

Di sisi lain, perubahan sistem menjadi digital dan online dengan segala kemudahan dan kepraktisannya, disadari atau tidak secara perlahan akan mempengaruhi pola pikir serta budaya belajar mengajar yang merupakan salah satu pilar penting dalam pendidikan. Meningkatkan budaya belajar mengajar yang baik akan sangat berpotensi untuk meningkatkan reputasi sekolah. (Sudrajat, 2011) mengutip pendapat Nursyam, setidaknya ada tiga jenis budaya baik yang perlu dikembangkan di sekolah, yaitu kultur akademik, kultur sosial budaya, dan kultur demokratis. Budaya sekolah memiliki pengaruh positif dalam proses belajar hanya jika hal itu dilakukan dengan serius dan 
konsisten untuk mencapai misi prestasi akademis. Budaya belajar-mengajar merupakan bagian dari budaya sekolah yang perlu ditingkatkan terus menerus untuk meningkatkan reputasi sekolah.

Kualitas atau mutu proses belajar mengajarlah yang akan berpengaruh pada prestasi dan reputasi sekolah. Menurut (Umaedi, 1999) prestasi sekolah dapat juga berupa kondisi yang tidak dapat dipegang secara fisik (intangible) seperti suasana disiplin, keakraban, saling menghormati, kebersihan dan sebagainya. Sementara itu menurut (Sagala, 2013) bahwasanya mutu adalah berkenaan dengan penilaian bagaimana suatu produk memenuhi kriteria, standar atau rujukan tertentu. Sedangkan (Supriyanto, 1997) menerangkan bahwa kualitas mengandung makna bobot atau tinggi rendahnya sesuatu, dalam hal ini kualitas pendidikan adalah pelaksanaan pendidikan di suatu lembaga yang sampai dimana pendidikan tersebut telah mencapai suatu keberhasilan.

Reputasi merupakan aset penting dan wajib dimiliki oleh suatu lembaga sebagai bukti keberadaan dan kualitas lembaga tersebut. Reputasi sekolah menunjukkan kualitas pendidikan sekaligus pencapaian prestasi sekolah sebagai indikator keberhasilan program pendidikan sekolah (Kurnia, 2013).

Dalam makalah ini akan dijelaskan dan dianalisis secara kualitatif pengaruh penerapan sistem monitoring pembelajaran online terhadap peningkatan budaya belajar mengajar dan reputasi sekolah yang baik melalui parameter terbatas seperti kehadiran peserta didik, kehadiran pendidik dan durasi waktu proses belajar mengajar.

\section{METODOLOGI}

Metode yang dipakai dalam studi ini sedikit banyak didasarkan pada teori pembelajaran yang bersifat preskriptif yaitu yang ide dasarnya adalah terkait dengan upaya mengendalikan variabel yang dimanipulasi dalam teori belajar agar memudahkan manusia dalam belajar. Termasuk di antaranya adalah Teori belajar behavioristik dan Konstruktivistik (Budiningsih, 2005).

Metode yang dipakai dalam studi yang dijelaskan dalam makalah ini diawali dengan pembuatan sistem monitoring pembelajaran online dan diterapkan pada prodi sarjana Teknik Kelautan di Departemen Teknik Kelautan (DTK) Fakultas Teknologi Kelautan (FTK) - ITS sebagai sebuah kegiatan pengabdian kepada masyarakat (abdimas). Sistem monitoring pembelajaran online ini berupa sebuah sistem berbasis web dan database server yang mampu merekam parameterparameter kegiatan belajar mengajar. Sistem ini selanjutnya diterapkan pada sekolah di sekitar kampus ITS Surabaya (AI Uswah Surabaya) sebagai mitra kegiatan.

Secara umum data yang direkam oleh sistem monitoring ini adalah: (1) waktu kehadiran pendidik (dosen/guru), (2) waktu kehadiran peserta didik (mahasiswa/murid), (3) materi ajar pada tiap pertemuan di kelas, dan (4) nilai evaluasi siswa. Keempat data pokok tersebut selanjutnya dapat diolah yang menghasilkan berbagai macam data rekapitulasi sehingga nantinya dapat digunakan sebagai bahan evaluasi guna mendapatkan capaian tertentu.

Data rekapitulasi ini selanjutnya ditelaah dan dianalisis serta diinterpretasikan terkait dengan parameter utama yang menjadi interes dalam studi ini, yaitu seperti:

1. Budaya belajar-mengajar

2. Ketuntasan materi ajar

3. Kinerja pengajar dan peserta didik

4. Reputasi sekolah

5. Promosi dan partisipasi

Selanjutnya parameter-parameter penting tersebut akan ditelaah korelasinya terhadap aspek kualitas budaya proses belajar mengajar dan reputasi sekolah sebagai konsekuensi diterapkannya sistem monitoring berbasis online. Telaah ini melalui data studi kasus yang disimulasikan secara sederhana.

Data yang digunakan dalam penelitian ini adalah data primer dan data sekunder. Data primer berupa hasil rekapitulasi sistem monitoring pembelajaran secara online dan data sekunder berupa hasil Forum Group Discussion (FGD) antara pihak pihak pengabdi, mitra pengabdian masyarakat, dan tim pengembang sistem. Data sekunder lainnya juga diperoleh dari studi dokumen yang berupa profil sekolah, data guru dan karyawan.

Tabel 1. Rekapitulasi pelaksanaan pembelajaran berdasar mata pelajaran beserta target dan capaiannya. 


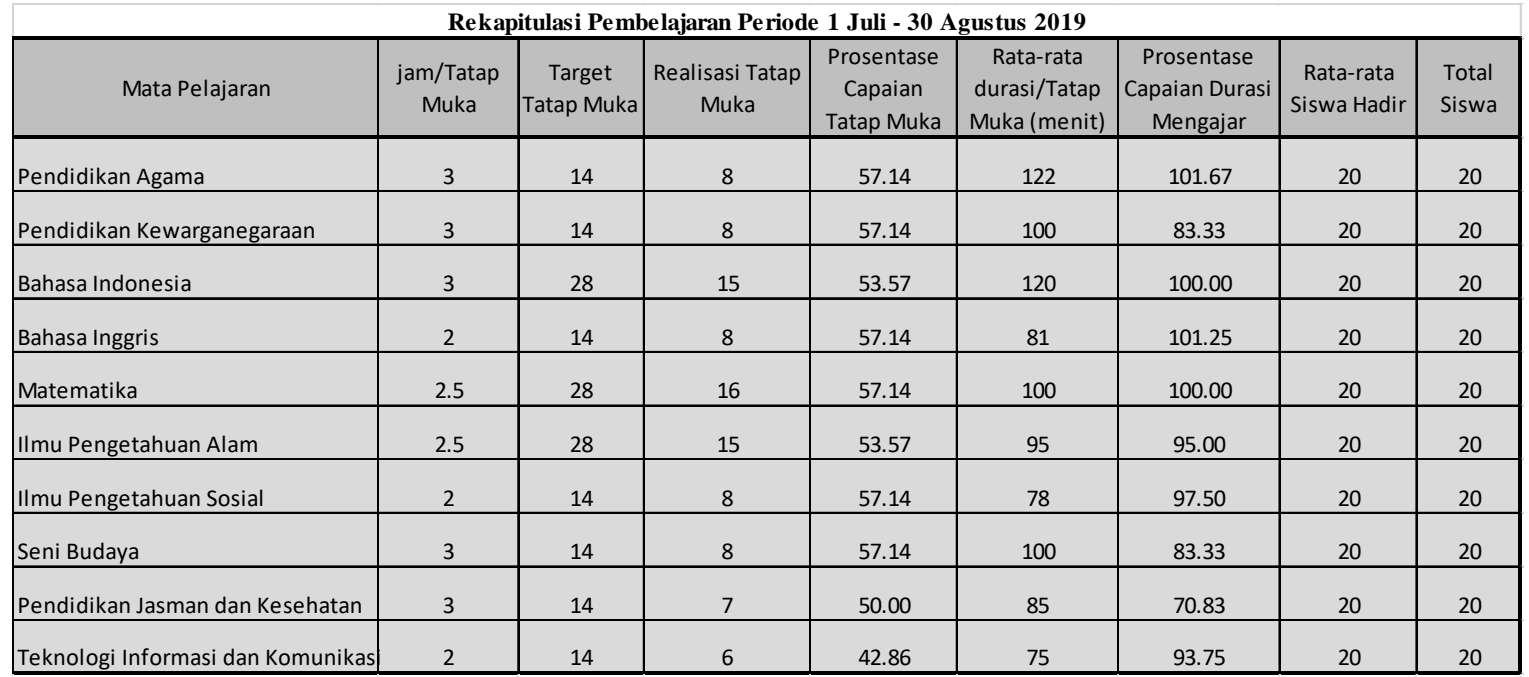

\section{HASIL DAN PEMBAHASAN}

Hadirnya sistem monitoring online ini mampu menyajikan data secara realtime terkait proses pembelajaran yakni meliputi waktu kehadiran siswa, waktu kehadiran pendidik, materi ajar, dan nilai evaluasi siswa. Sistem ini dapat diakses oleh pendidik, siswa, manajemen sekolah, dan orang tua/wali siswa. Dengan demikian proses belajar-mengajar akan menjadi terarah, terukur, mudah dipantau dan dievaluasi serta obyektif-transparan.

Kegiatan diskusi (FGD) juga dilakukan antara tim pengabdi, mitra pengabdian dan tim pengembang sistem untuk mendapatkan data sekunder guna memperkuat analisis atas efek hadirnya sistem pembelajaran online terhadap peningkatan budaya belajar mengajar dan reputasi sekolah mitra pengabdian.

Semua data simulasi untuk studi kasus telah direkam dan diolah secara sederhana. Sebagai contoh hasil rekapitulasinya disajikan dalam Tabel 1 hingga Tabel 3. Tabel 1 adalah hasil rekapitulasi pelaksanaan pembelajaran yang meliputi durasi waktu tatap muka, target, realisasi waktu pelaksanaan dan disertai dengan kualitas capaiannya. Tabel 2 menyajikan contoh rekapitulasi kehadiran pendidik dari suatu mata pelajaran tertentu (Bahasa Indonesia) untuk beberapa pertemuan kelas. Sedangkan Tabel 3 menampilkan rekapitulasi kehadiran peserta didik suatu mata pelajaran untuk suatu pertemuan kelas.

Tabel 2. Rekapitulasi kehadiran pendidik (1 jam pelajaran adalah 40 menit).

Rekapitulasi Kehadiran Pendidik

Nama : Yuni Kartika

Mata Pelajaran : Bahasa Indonesia

Jam/Tatatp Muka : 3

\begin{tabular}{|c|c|c|c|c|}
\hline Pertemuan & Tanggal & Jam Mulai & Jam Akhir & Durasi \\
\hline 1 & $1 / 7 / 2019$ & $8: 05$ & $10: 05$ & 120 \\
\hline 2 & $8 / 7 / 2019$ & $8: 04$ & $10: 00$ & 124 \\
\hline 3 & $15 / 7 / 2019$ & $8: 07$ & $10: 02$ & 115 \\
\hline 4 & $22 / 7 / 2019$ & $7: 58$ & $10: 02$ & 124 \\
\hline 5 & $29 / 7 / 2019$ & $7: 59$ & $10: 00$ & 121 \\
\hline 6 & $5 / 7 / 2019$ & $8: 10$ & $10: 05$ & 115 \\
\hline 7 & $12 / 7 / 2019$ & $8: 01$ & $10: 04$ & 123 \\
\hline 8 & $19 / 7 / 2019$ & $8: 00$ & $10: 05$ & 125 \\
\hline
\end{tabular}


Tabel 3. Rekapitulasi kehadiran peserta didik.

Rekapitulasi Kehadiran Siswa

\begin{tabular}{ll} 
Nama Guru & $:$ Yuni Kartika \\
Mata Pelajaran & $:$ Bahasa Indonesia \\
Pertemuan ke- & $: 1$ \\
Tanggal & $: 3$ Agustus 2019 \\
\hline
\end{tabular}

Tanggal $\quad: 3$ Agustus 2019

\begin{tabular}{|l|c|c|c|c|}
\hline \multicolumn{1}{|c|}{ Nama Siswa } & No.Induk & Jam Mulai & Jam Akhir & Keterangan \\
\hline Aditya Wicaksono & 4309100038 & $8: 05$ & $10: 05$ & Hadir \\
\hline Ian Vito Rahmad Perdana & 4309100047 & $8: 05$ & $10: 05$ & Hadir \\
\hline Jalisman Filihan & 4309100080 & $8: 05$ & $10: 05$ & Hadir \\
\hline Teuku Sulthan Puri & 4309100701 & $8: 05$ & $10: 05$ & Hadir \\
\hline Paramasatya Rahayu & 4310100063 & $8: 05$ & $10: 05$ & Hadir \\
\hline Dimas Meidhika Pusuratama & 4310100068 & $8: 05$ & $10: 05$ & Hadir \\
\hline Donny Yusuf Mimbar & 4310100071 & $8: 05$ & $10: 05$ & Hadir \\
\hline Windra Bangun Nuswantoro & 4310100076 & - & - & Izin \\
\hline Rahmat nopian & 4310100029 & $8: 05$ & $10: 05$ & Hadir \\
\hline Muchammad Ibnu Athoillah & 4310100085 & $8: 05$ & $10: 05$ & Hadir \\
\hline Dimas Wahyu Arie Chandra & 4311100005 & $8: 05$ & $10: 05$ & Hadir \\
\hline Widhi Yuliarta Hidayat & 4311100008 & $8: 05$ & $10: 05$ & Hadir \\
\hline Rozy Yuwafi Hasan & 4311100010 & $8: 05$ & $10: 05$ & Hadir \\
\hline Firza Redana & 4311100011 & $8: 05$ & $10: 05$ & Hadir \\
\hline
\end{tabular}

Untuk menunjukkan korelasi terkait hadirnya sistem pembelajaran online terhadap peningkatan budaya belajar mengajar dan reputasi sekolah serta aspek lain yang terkait maka analisis kualitatif dan pembahasan hasil kegiatan difokuskan pada 4 hal pokok yaitu terkait dengan (i) kinerja sekolah, (ii) budaya belajar-mengajar, (iii) partisipasi orang tua, dan (iv) reputasi sekolah.

Data kehadiran siswa pada setiap mata pelajaran yang bisa diakses secara online memungkinkan setiap saat orang tua dapat memonitor presensi putra-putrinya dalam aktifitas belajar mengajar di sekolah. Dengan mengetahui secara langsung seperti ini akan meningkatkan ketenangan dan kepercayaan wali murid terhadap sekolah, karena tidak jarang kasus siswa pergi ke sekolah tetapi belum tentu mengikuti pelajaran di kelas. Hal ini tentu selanjutnya akan berdampak positif pada reputasi sekolah. Hak akses orang tua pada sistem monitoring sementara hanya terbatas pada informasi kehadiran pada setiap mata pelajaran per harinya.

Data kehadiran pendidik (guru/dosen) akan menjadi parameter yang sangat penting sebagai indikator kedisiplinan dan ketertiban aktivitas belajar-mengajar. Sistem monitoring yang bersifat realtime yang dipadukan dengan data prosentase capaian dan feedback dari peserta didik/siswa akan mampu diterjemahkan ke dalam penilaian kinerja pendidik itu sendiri. Pendidik dengan prosentase capaian di atas $100 \%$ misalnya, tentu akan dinilai dan diperlakukan berbeda oleh manajemen sekolah dengan pendidik yang capaiannya di bawah $80 \%$. Faktor capaian mengajar ini bisa menjadi pertimbangan mendasar dalam melakukan evaluasi kinerja pendidik. Umpan balik dari peserta didik terhadap kesesuain materi ajar, ketepatan dan kesesuaian waktu juga dapat menjadi faktor penguat kualitas pendidik dalam menumbuhkan budaya belajar-mengajar yang lebih baik.

Data rekapitulasi dari sistem monitoring pembelajaran apabila diikuti dengan upaya perbaikan berkelanjutan terhadap kualitas individu pendidik maka kualitas proses belajar mengajar akan meningkat. Budaya belajar-mengajar yang lebih baik akan menghasilkan siswa berprestasi unggul, selanjutnya akan berdampak pada reputasi sekolah.

\section{Kinerja Sekolah}

Proses belajar-mengajar tidak hanya berfokus pada pendidik dan peserta didik semata, namun diperlukan kehadiran manajemen sekolah untuk mewadahi dan mengelola semua elemen yang ada. Sejauh mana dampak dari hadirnya teknologi sistem pembelajaran online terhadap kinerja manajemen sekolah baik untuk supporting activities maupun untuk tercapainya outcome yang sudah ditetapkan mampu ditunjukkan dalam analisis ini. Jauh sebelum penggunaan sistem monitoring ini, proses absensi dan rekapitulasi kehadiran peserta didik dan pendidik masih mengunakan sistem konvesional. Dalam pelaksanaannya memerlukan waktu dan sumberdaya manusia khusus untuk 
pengumpulan data fisik, klasifikasi dan rekapitulasi yang masih sangat besar kemungkinan terjadinya human error. Penggunaan sistem monitoring online mampu memberikan solusi yang efektif dan efisien dalam pelaksanaanya baik meliputi waktu, sumber daya manusia dan kualitas data/hasil kegiatan. Kepala sekolah atau pimpinan manajemen memiliki fungsi pengawasan terhadap pendidik maupun peserta didik untuk memastikan proses belajar-mengajar dapat berjalan dengan baik dan lancar. Dengan sistem online ini dapat memberikan kemudahan memonitor kinerja pendidik dan peserta didik. Berdasar fakta tersebut adanya sistem monitoring pembelajaran online berkorelasi langsung secara positif dengan dampak kinerja manajemen sekolah akan semakin baik/meningkat.

\section{Budaya Belajar-Mengajar}

Dalam pelaksanaan proses belajar mengajar terjadi interaksi antara pendidik (guru/dosen) dengan peserta didik (murid/mahasiswa) yang harus dijamin kualitasnya. Menurut Mangieri bahwa 8 (delapan) kondisi yang memungkinkan semua lembaga pendidikan mencapai keunggulan yaitu: (1) kurikulum yang ketat, (2) guru yang kompeten, (3) adanya ciri-ciri keefektifan, (4) testing untuk membuktikan bahwa siswa telah memenuhi capaian tertentu, (5) dukungan masyarakat dan keterlibatan orang tua, (6) pembiayaan yang memadai (7) disiplin yang kuat, dan (8) keterkaitan pada nilai-nilai tradisional (Ardana, 1997).

Hadirnya sistem monitoring pembelajaran ini dapat memenuhi beberapa aspek terkait efektifitas, guru yang kompeten, dukungan orang tua dan disiplin. Efektifitas dalam kegiatan belajarmengajar salah satunya ditunjukkan dengan proses absensi yang menggunakan teknologi informasi dan komunikasi (TIK) telah terbukti memberikan berbagai manfaat dibandingkan menggunakan metode konvensional. Pendidik yang kompeten salah satunya dapat diketahui melalui parameter kehadiran dan komitmen dalam pembelajaran yang dapat tersimpan pada database sistem monitoring. Di samping itu umpan balik peserta didik terhadap kesesuain materi dan kesesuaian durasi tatap muka yang disampaikan tenaga pendidik akan memperkuat kualitas data dalam menggambarkan profil seorang tenaga pendidik. Kemampuan sistem monitoring untuk menyimpan data waktu mulai dan berakhirnya proses belajar-mengajar, akan menjadi data valid dan tidak mudah dimanipulasi yang dapat menunjukkan tingkat kedisiplinan tenaga pendidik dan peserta didik. Melalui beberapa parameter tersebut perbaikan budaya belajar-mengajar yang melibatkan beberapa pihak dapat diwujudkan.

\section{Partisipasi Orang Tua}

Keterbatasan informasi bagi orang tua terhadap anaknya selama di sekolah masih terjadi apabila inovasi teknologi tidak dihadirkan atau dimanfaatkan untuk penyelenggaraan pendidikan. Misalnya, orang tua yang selama ini biasanya hanya mendapatkan informasi prestasi belajar siswa di akhir semester, maka mereka seolah tidak memiliki kesempatan untuk segera berperan dalam membantu mendorong prestasi siswa yang kurang baik di saat semester masih berjalan. Demikian pula misalnya terhadap siswa yang bermasalah. Boleh dikata sesuatunya serba terlambat, tidak sempat berbuat lebih dini yang antisipatif. Maka dengan sistem monitoring pembelajaran online ini mereka dapat mengetahui sebagian proses belajar dan kondisi putra-putrinya secara realtime, sehingga partisipasinya meningkat dan makin efektif. Hal ini akan mampu menambah kepercayaan terhadap sekolah yang pada gilirannya akan mampu menciptakan efek bola salju atas partispasi orang tua dalam proses belajar mengajar di sekalah menjadi lebih luas lagi.

\section{Reputasi sekolah}

Dari berbagai analisis dan fakta kebermanfaatan hadirnya teknologi informasi dan komunikasi (TIK) dengan sistem monitoring pembelajaran online ini secara langsung maupun tidak langsung dapat mempengaruhi reputasi sekolah. Reputasi dibangun oleh mutu/kualitas. Data rekapitulasi dari sistem monitoring pembelajaran apabila diikuti dengan semangat untuk terus menerus melakukan perbaikan kualitas individu pendidik, peserta didik dan manajemen maka kualitas proses belajar mengajar akan meningkat. Hal ini juga berlaku sebaliknya, apabila data rekapitulasi yang menggambarkan kondisi real proses belajar-mengajar tidak disikapi secara bijak dan positif maka justru akan menjadi bumerang, kontra produktif berujung reputasi negatif. Manajemen sekolah, pendidik dan anak didik yang berkualitas akan membentuk budaya belajar-mengajar yang unggul, hal ini akan sangat berdampak pada reputasi sekolah.

Di sisi lain, reputasi sekolah yang baik akan menambah kepercayaan orang tua dan secara tidak langsung akan mampu menjadikan mereka sebagai agen-agen promosi sekolah. Nuansa dan nada komunikasi mereka terhadap masyarakat sekitarnya bisa bersifat promotive yang sangat ampuh 
dan efektif untuk membentuk image sekolah yang baik dan unggul di mata masyarakat. Otomatis animo masyarakat terhadap sekolah tersebut akan meningkat yang mana hal ini sangat diperlukan bagi keberlanjutan sekolah.

\section{KESIMPULAN}

Tiga parameter penting dalam proses belajar-mengajar meliputi kehadiran pendidik, kehadiran peserta didik dan kualitas capaian mampu menggambarkan kualitas proses belajar-mengajar yang menjadi kunci mutu pendidikan.

Reputasi sekolah sangat dipengaruhi oleh mutu/kualitas para pemangku kepentingannya (stake holders) yakni pendidik, peserta didik, manajemen sekolah, dan orang tua, yang saling memiliki keterkaitan dalam proses belajar-mengajar sehingga parameter penting untuk mencapai keberhasilan penyelenggaraan pendidikan dapat terukur dan dicapai.

Hadirnya sistem monitoring pembelajaran online secara realtime dengan segala kelebihannya mampu menghasilkan data yang dapat dikorelasikan dengan lebih efektif dan efisien terhadap 4 hal pokok yaitu terkait dengan (i) kinerja sekolah, (ii) budaya belajar-mengajar, (iii) partisipasi orang tua, dan (iv) reputasi sekolah. Korelasi tersebut dapat menjadi positif atau negatif bergantung pada respon yang diambil berdasar data yang sudah tersaji dengan baik dan mencukupi tersebut.

\section{UCAPAN TERIMAKASIH}

Penulis berterima kasih dan memberikan penghargaan yang setinggi-tingginya kepada Departemen Teknik Kelautan ITS Surabaya yang telah memberikan pendanaan untuk kegiatan ini melalui skema Pengabdian Masyarakat Dana Departemen dan pihak lembaga pendidikan Al-Uswah Surabaya sebagai mitra kegiatan. Juga terimakasih kepada pihak LPPM ITS yang telah membantu mengorganisir proses administrasi kegiatan ini.

\section{REFERENCES}

Anand, S., Kamal, B., Sheeja, S., Praphul, P., (2016). Attendance Monitoring in Classroom Using Smartphone \& Wi-Fi Fingerprinting.

Ardhana, W. Pembelajaran Unggul, 1997.

Budiningsih, A. C, 2005. Belajar dan Pembelajaran, Rineka Cipta: Jakarta.

Firdaus., A., (2011). Rancang Bangun Sistem Monitoring Perkuliahaan Berbasis Web di Fakultas Teknik Universitas Sriwijaya.

Kurnia I. H., 2013. Strategi Humas dalam Meningkatkan Reputasi Sekolah (Studi Kasus di SMA Negeri 1 Surakarta). Jupe UNS, Vol. I, No. 2, Hal 1 s/d15.

Puspitasari, S.N. 2016. Teknologi Atasi Masalah Pendidikan, (online), (https://www.pikiranrakyat.com/pendidikan/2016/10/13/teknologi-atasi-masalah-pendidikan-382126), diakses 13 Agustus 2019

Sagala, S., 2013. Manajemen Strategik dalam Peningkatan Mutu Pendidikan. Bandung: Alfabeta, CV.

Sudrajat, A, 2011. "Mengapa Pendidikan Karakter?", Jurnal Pendidikan Karakter.

Supriyanto, A, 1997. Jurnal IImu Pendidikan Mutu Pendidikan Sekolah Dasar Di Daerah Diseminasi, November 1997, Jilid 4, IKIP, 1997: 225.

Umaedi, 1999. Manajemen Peningkatan Mutu Berbasis Sekolah, Direktur Pendidikan Menengah dan Umum.

Wenda, P., dkk,. (2013). Sistem Informasi Monitoring Perkuliahan Berbasis Web Di Stmik Sinar Nusantara Surakarta. 